\title{
The invasive New Guinea flatworm Platydemus manokwari in France, the first record for Europe: time for action is now
}

Non-indigenous terrestrial flatworms (Platyhelminthes) have been recorded in thirteen European countries. They include Bipalium kewense and Dolichoplana striata that are largely restricted to hothouses and may be regarded as non-invasive species. In addition there are species from the southern hemisphere such as the invasive New Zealand flatworm Arthurdendyus triangulatus in the United Kingdom, Eire and the Faroe Islands, the Australian flatworm Australoplana sanguinea alba in Eire and the United Kingdom, and the Australian Blue Garden flatworm Caenoplana coerulea in France, Menorca and the United Kingdom. The United Kingdom has some twelve or more non-indigenous species most of which are Australian and New Zealand species. These species may move to an invasive stage when optimum environmental and other conditions occur, and the flatworms then have the potential to cause economic or environmental harm. In this paper, we report the identification (from morphology and molecular analysis of $\mathrm{COI}$ sequences) of non-indigenous terrestrial flatworms found in a hothouse in Caen (France) as the New Guinea flatworm Platydemus manokwari de Beauchamp, 1963 (Platyhelminthes, Continenticola, Geoplanidae, Rhynchodeminae). Platydemus manokwari is among the "100 World's Worst Invader Alien Species". Lists of World geographic records, prey in the field and prey in laboratories of $P$. manokwari are provided. This species is considered a threat to native snails wherever it is introduced. The recent discovery of $P$. manokwari in France represents a significant extension of distribution of this Invasive Alien Species from the Indo-Pacific region to Europe. If it escaped the hothouse, the flatworm might survive winters and become established in temperate countries. The existence of this species in France requires an early warning of this incursion to State and European Union authorities, followed by the eradication of the flatworm in its locality, tightening of internal quarantine measures to prevent further spread of the flatworm to and from this site, identifying if possible the likely primary source of the flatworm, and tracing other possible incursions that may have resulted from accidental dispersal of PeerJ reviewing PDF | (v2014:01:1372:1:0:NEW 9 Feb 2014) 
plants and soil from the site. 


\section{Jean-Lou Justine, Leigh Winsor, Delphine Gey, Pierre Gros, Jessica Thévenot}

2 Jean-Lou Justine, ISYEB, Institut de Systématique, Évolution, Biodiversité, UMR7205 CNRS,

3 EPHE, MNHN, UPMC, Muséum National d'Histoire Naturelle, CP 51, 55 rue Buffon, 75231

4 Paris cedex 05, France

5 Leigh Winsor, School of Marine and Tropical Biology, James Cook University, Townsville Qld 6 4811, Australia

7 Delphine Gey, UMS 2700 Service de Systématique moléculaire, Muséum National d'Histoire

8 Naturelle, CP 26, 57 rue Cuvier, 75231 Paris cedex 05, France

9 Pierre Gros, Amateur Naturalist, 26 Route de France, 06800 Cagnes-sur-Mer, France

10 Jessica Thévenot, Coordination technique et scientifique de la stratégie nationale relative aux

11 espèces exotiques envahissantes, Service du Patrimoine Naturel, Muséum National d'Histoire

12 Naturelle, CP 41, 36 rue Geoffroy Saint-Hilaire, 75231 Paris cedex 05, France

13 Corresponding Author: Jean-Lou Justine, justine@mnhn.fr 


\section{Introduction}

15 An undesirable consequence of globalization, a relatively modern phenomenon, has been an

16 increase in the number of biological invasions that challenge the conservation of biodiversity and

17 natural resources (Secretariat of NOBANIS 2012; Simberloff 2014). Invasive Alien Species

18 (IAS) have been defined as "plants, animals, pathogens and other organisms that are non-native

19 to an ecosystem, and which may cause economic or environmental harm or adversely affect

20 human health. In particular, they impact adversely upon biodiversity, including decline or

21 elimination of native species - through competition, predation, or transmission of pathogens - and

22 the disruption of local ecosystems and ecosystem functions" (Convention on Biological Diversity 23 2009).

24 Historic biological invasions include the passive dispersal of terrestrial flatworms, also known as 25 land planarians. The main driver for this was probably horticulturalists of the 19th Century using the then recently invented Wardian cases to safely transport back to the hothouses and gardens of Europe rare plants, together with soil containing cryptic exotic animal species (Winsor et al. 2004). As a consequence over 30 species of land planarians have established themselves as nonindigenous species in various countries outside their native range (Winsor et al. 2004).

In human-modified habitat flatworms and their cocoons continue to be associated with rooted and potted plants, rhizomes, and certain types of fresh vegetable produce (Alford et al. 1996). Subsequent secondary dispersal of these invasive flatworm species occurs through the exchange and purchase of plants from nurseries, botanical gardens, garden centres and gardeners (Alford et al. 1996) especially infested nurseries and garden centres (Boag et al. 1994; Moore et al. 1998), active inadvertent dispersal through social traditions of exchanging plants and recycling topsoil (Christensen \& Mather 1998), or through the deliberate introduction of flatworms for the purposes of biological control of a pest species such as the giant African snail Achatina fulica Bowdich, 1822 in the Pacific Region (Muniappan 1987; Waterhouse \& Norris 1987).

Land planarians are carnivores, and feed upon a variety of soil organisms such as earthworms, isopods, insects and snails, and some IAS flatworms may pose a threat to local biodiversity (Alford et al. 1996; Cowie 2010; Santoro \& Jones 2001; Ducey et al 2007; Sugiura

43 2010) and negatively impact on agriculture, for example through a decline in earthworms species

44 (Murchie \& Gordon 2013) resulting in reduced soil fertility (Murchie 2010) and possibly

45 drainage (Jones et al. 2001). 
Non-indigenous terrestrial flatworms have been recorded in thirteen European countries

47 (Filella-Subirá 1983; Jones 1998; Kawakatsu et al 2002; Ogren et al. 1997). These flatworms can

48 be divided into two broad groups: the "old" and the "new" introduced species.

The “old” group includes Bipalium kewense Moseley, 1878 and Dolichoplana striata

50 Moseley, 1877 that were undoubtedly inadvertently introduced to Europe in the 19th Century by

51 horticulturalists. One or both these species are present in ten European countries, and are the only

52 non-indigenous flatworms presently recorded in Austria, Belgium, Czech Republic, Finland,

53 Germany, Norway, Poland, and Portugal. These two species appear to be largely restricted to

54 hothouses in Europe and do not meet the foregoing criteria for Invasive Alien Species; the species

55 are widespread but exist in localized populations, and may be better regarded as non-invasive species. However such species may move to an invasive stage when optimum environmental and other conditions for the species occur, and the flatworms then have the potential to impact on soil fauna, especially earthworms as has occurred in areas of North America with Dolichoplana striata (Hyman 1954) and Bipalium species (Ducey et al 2005, 2007).

The "new" group of non-indigenous flatworms present in Europe includes mainly species

61 from the southern hemisphere such as the IAS New Zealand flatworm Arthurdendyus triangulatus (United Kingdom, Eire, Faroe Islands), the Australian flatworm Australoplana sanguinea alba (Moseley, 1877) (Eire, United Kingdom), and the Australian Blue Garden flatworm Caenoplana coerulea Moseley, 1877 (United Kingdom, France, and recently Menorca (Breugelmans et al. 2012) and Spain (Mateos et al. 2013)). The United Kingdom has some twelve or more non-indigenous species most of which are Australian and New Zealand species (Jones 67 2005).

We recently identified non-indigenous terrestrial flatworms found in a hothouse in Caen (France) as the New Guinea flatworm Platydemus manokwari de Beauchamp, 1963. The identity

70 of these flatworms was subsequently confirmed by molecular analysis of COI sequences.

71 Platydemus manokwari is among the "100 World's Worst Invader Alien Species" (Lowe et al.

72 2000). In this paper, we present evidence for the identification of the species in France, the first 73 record in Europe, and provide a brief review of the records of the species in the world, lists of its 74 known prey, and possible control options.

\section{Material and Methods}

76 Material 
77 Specimens were found in a hothouse in the Jardin des Plantes in Caen (France); according to

78 witnesses, it is likely that similar specimens were present in the hothouse for months. Specimens

79 were collected by hand and sent alive to Paris by postal service. Eight specimens were processed.

80 Five were kept alive and used for prey experiments and detailed photographs; they died after

81 several days and were discarded. Three were killed in hot water and then stored in ethanol

82 (specimens JL81A and JL81B) or formalin (JL81C). A small piece of the body was taken from

83 the two ethanol-fixed individuals for molecular analysis. Photographs were forwarded to one of

84 us (LW) for identification. Histological anatomical investigations were not undertaken at this

85 time. Specimens are deposited in the collections of the Muséum National d'Histoire Naturelle,

86 Paris, under registration number MNHN JL81A-C.

87 Limited prey experiments were undertaken with the few living available specimens; very

88 simply, flatworms were put in a small plastic container with living snails.

\section{Molecular sequences}

90 Genomic DNA was extracted from a small piece of the worm, using the QIAamp DNA Mini Kit

91 (Qiagen). A fragment of $424 \mathrm{bp}$ of COI gene was amplified with the primers COI-ASmit1

92 (forward 5'-TTTTTTGGGCATCCTGAGGTTTAT-3') and COI-ASmit2 (reverse 5'-

93 TAAAGAAAGAACATAATGAAAATG-3') (Littlewood et al. 1997). The PCR reaction was

94 performed in $20 \mu \mathrm{l}$, containing $1 \mathrm{ng}$ of DNA, $1 \times$ CoralLoad PCR buffer, $3 \mathrm{Mm} \mathrm{MgCl} 2,66 \mu \mathrm{M}$ of

95 each dNTP, $0.15 \mu \mathrm{M}$ of each primer, and 0.5 units of Taq DNA polymerase (Qiagen). The

96 amplification protocol was: $4^{\prime}$ at $94^{\circ} \mathrm{C}$, followed by 40 cycles of $94{ }^{\circ} \mathrm{C}$ for $30^{\prime \prime}, 48^{\circ} \mathrm{C}$ for $40^{\prime \prime}$,

$9772^{\circ} \mathrm{C}$ for 50 ", with a final extension at $72^{\circ} \mathrm{C}$ for 7 . PCR products were purified and sequenced

98 in both directions on 3730xl DNA Analyzer 96-capillary sequencer (Applied Biosystems).

99 Sequences were edited using CodonCode Aligner software (CodonCode Corporation, Dedham,

100 MA, USA), compared to the GenBank database content using BLAST and deposited in GenBank

101 under accession number KF887958. Sequences were compared using MEGA5 (Tamura et al.

102 2011). 
104 Morphology

105 The flatworm was broadest in the middle, tapering evenly anteriorly but more abruptly

106 posteriorly (Figure 1). Two large prominent eyes were situated back from the tip of the elongate

107 snout-like head (Figure 2). In cross section the flatworm was convex dorsally and flat ventrally.

108 The figured live mature specimen was $50 \mathrm{~mm}$ long and $5 \mathrm{~mm}$ wide. The mouth was located just

109 behind the midpoint of the ventrum, with gonopore about half way between the mouth and

110 posterior end. The dorsum was a dark olive brown colour, which under a lens showed a fine pale

111 brownish graininess. A pale cream median dorsal longitudinal stripe, some $0.3 \mathrm{~mm}$ wide, began

112 just behind the eyes and continued to the posterior tip (Figures 1 and 3). The olive brown colour

113 graded to grey at the anterior tip. A thin submarginal cream stripe with fine lower greyish margin

114 ran laterally from the anterior end along the length of the body (Figure 3). The ventral surface

115 was a pale finely mottled light brown (Figures 4-5), slightly paler mid ventrally. These features

116 are consistent with those of Platydemus manokwari de Beauchamp, 1963 (Platyhelminthes,

117 Continenticola, Geoplanidae, Rhynchodeminae) (de Beauchamp 1962; Kawakatsu et al. 1992;

118 Winsor 1990).

\section{Prey Experiments}

120 Various living snails were introduced in the same container as a single flatworm. Four out of the

1215 specimens died before feeding. A single prey event, on the helicid Eobania vermiculata Müller,

1221774 was observed. The cylindrical pharynx, protruding from the ventral surface, was visible

123 when the flatworm was preying on a snail (Figure 5).

\section{Molecular identification}

125 The two COI sequences we obtained from two individuals were identical. They were compared to

126 the only available COI sequences of a member of the genus Platydemus in GenBank (Platydemus

127 manokwari; Accession number: AF178320.1). The p-distance between our new sequence and the

128 GenBank sequence of Platydemus manokwari was 4\%. Although this is not mentioned in the

129 GenBank record, we know that this specimen was collected in Australia by one of us (LW). The

130 population from which the GenBank example of Platydemus manokwari (AF178320.1) was

131 taken had previously been confirmed histologically (by LW from lot LW1065) as P. manokwari 
132 and voucher specimens lodged in the Queensland Museum (Registration numbers GL4724,

133 whole specimen in alcohol, and GL4725, 126 slides).

\section{Nomenclatural clarification}

135 There is some variation in the literature about the date of description of P. manokwari, 1962 or

136 1963. We carefully examined the original publication. The paper was presented at a meeting in 137 December 1962 and is included in the volume dated 1962, but the actual date of publication was

138 April 18, 1963. In accord with Article 21.1 (International Commission on Zoological

139 Nomenclature 1999), the date of the taxon is 1963. The bibliographical date of the publication 140 remains 1962, but the taxon is Platydemus manokwari de Beauchamp, 1963.

\section{Discussion}

\section{Molecular identification}

143 The p-distance between our two sequences and the GenBank sequence of Platydemus manokwari 144 was $4 \%$. This genetic distance roughly corresponds to the genetic distances generally found 145 between closely related species or distant populations within a single species. Alvarez-Presas et 146 al. (2012) studied variation of COI in species belonging to the same family as Platydemus 147 manokwari, i.e. the Geoplanidae. In this study of the European species Microplana terrestris 148 (Müller, 1774), specimens were studied from two localities, East and West of Northern Spain. 149 Variation ranged from $0 \%$ to $3 \%$ within the western localities, and from $0 \%$ to $1.6 \%$ in the eastern 150 localities; West and East presented a difference of $2.4 \%$ to $4 \%$. The between-species difference 151 (M. terrestris vs M. robusta Vila-Farré and Sluys, 2011) was about 19\%. Therefore, we consider 152 that the difference of $4 \%$ found between our French specimens of $P$. manokwari and the 153 Australian specimen in GenBank is compatible with intraspecific variation. The molecular data 154 thus confirm the morphological identification.

\section{Previous records of land planarians in France}

156 Previous records of non-indigenous land planarians in France include a Pelmatoplana sp. from a

157 greenhouse in Saint Max, a suburb of Nancy (identified by de Beauchamp in Remy 1942);

158 Bipalium kewense and Caenoplana coerulea from an urban garden in Villeneuve-de-la-Raho, 159 department of Pyrénées-Orientales (mentioned as "France" in Winsor et al. 2004), where potted 160 plants purchased from a local plant supermarket were believed to be the source of the flatworms 
161 (Gérard Peaucellier, in litt); Bipalium kewense in Orthez and Bayonne, department of Pyrenées-

162 Atlantiques (Vivant 2005).

163 Other species, often unidentified, have been recorded recently in France in newspapers

164 (Gasiglia 2013; Guyon 2014; Heyligen 2013), magazines (Groult \& Boucourt 2014) and blogs

165 (Justine 2013) and mentioned in governmental documents (Placé 2013), but not in published

166 scientific publications.

167 The occurrence of the invasive flatworm Platydemus manokwari in the Jardin des

168 Plantes, Caen, in the department of Basse-Normandie (Normandy, France), is the first record of

169 the species in Europe.

\section{Previous records of Platydemus manokwari}

171 Platydemus manokwari occurs at Pindaunde station, Mt Wilhelm at 3625 metres altitude (de 172 Beauchamp 1972; Winsor 1990), where it was found under stones together with Platydemus 173 longibulbus de Beauchamp, 1972 and Platydemus pindaudei de Beauchamp, 1972, and at 174 Kainantu at 1558 metres altitude in the eastern highlands of New Guinea (Winsor 1990). The 175 natural range of this upland species has yet to be determined.

176 Until now, Platydemus manokwari was confined to the Indo-Pacific region within the

177 bounds of the Ogasawara Islands, Japan in the north; near Mackay in Queensland, Australia to the 178 south; French Polynesia to the east; with the most westerly extent of the flatworm in the

179 Maldives. The Caen record of this species is a significant westerly extension of the occurrence of 180 P. manokwari from the Indo-Pacific region to Europe.

181 Since it was first discovered in the Agricultural Research Station in Manokwari, Irian Jaya

182 in 1962 where it was credited with the decline of the Giant African Snail Achatina fulica, an

183 invasive pest of coconut plantations and other crops (Mead 1963; Mead 1979; Muniappan et al.

184 1986; Schreurs 1963; van Driest 1968; Waterhouse \& Norris 1987), Platydemus manokwari has

185 progressively spread throughout the Indo-Pacific (Table 1). The flatworm has been accidently

186 introduced, probably together with plants and soil, to various islands in the Pacific region

187 including Australia, Guam, Palau, Hawaii, Federated States of Micronesia, French Polynesia, and

188 Samoa. The most recent report of P. manokwari in the Pacific region is its occurrence in Rotuma

189 in the Fiji archipelago (Brodie et al. 2013). The flatworm was also deliberately introduced as a

190 bio-control agent for the Giant African Snail Achatina fulica to Bugsuk in the Philippines

191 (Muniappan et al. 1986; Waterhouse \& Norris 1987), Yokohama, Japan (Eldredge \& Smith 1995),

192 and the Maldives (Muniappan 1987). The rate of secondary dispersal of Platydemus manokwari 
193 is low and depends upon transport of infected plants and soil, or the flatworms themselves, by

194 humans. The flatworms appear to be incapable of travelling long distances on their own, having

195 taken 12 months to colonize mixed urban garden habitats separated by some 30 metres of lawn

196 (Winsor 1990), and on Fua Mulaku (Maldives) cleared Achatina for a radius of 180 metres from

197 the release site over the period of a year (Muniappan 1987).

\section{Reproduction}

199 Under experimental conditions the optimum temperature for rearing P. manokwari in terms of

200 pre-oviposition period and cocoon production is $24^{\circ} \mathrm{C}$, with a mean post-oviposition

201 developmental period for the young to hatch from the cocoon of 7.8 \pm 1.2 days (Kaneda et al.

202 1992). Cocoons contain an average of 5.2 juveniles (3-9) each. The flatworm begins oviposition

203 within 3 weeks of hatching (Kaneda et al. 1992). The temperature threshold for oviposition lies

204 between $15^{\circ} \mathrm{C}$ and $18^{\circ} \mathrm{C}$, and for cocoon and juvenile stages $10^{\circ} \mathrm{C}$ and $11.7^{\circ} \mathrm{C}$ respectively

205 (Kaneda et al. 1992). The flatworm normally reproduces sexually, and does not appear to

206 reproduce by fission (Kaneda et al. 1990).

\section{Biology}

208 Platydemus manokwari prefers wet humid conditions and is unable to survive in completely dry

209 habitats; high humidity and adequate precipitation are essential for the survival of the flatworm

210 (Kaneda et al. 1990; Sugiura 2009). The flatworm is diurnal if the moisture conditions are right

211 (Kaneda et al. 1990). Temperature appears to influence predation rate by the flatworm in field and

212 laboratory experiments, and also its survival. Sugiura (2009) considers that $10^{\circ} \mathrm{C}$ is a possible

213 threshold temperature for the establishment of P. manokwari, and speculates that low winter

214 temperatures may have restricted the invasion and establishment of P. manokwari in temperate

215 countries.

216 Platydemus manokwari, like a number of other rhynchodemines of the Australia-New

217 Guinea region, appears to be an upland species that naturally range from alpine through to sub-

218 alpine, cool temperate and warm temperate zones to tropical climates. At the Pindaunde station

219 on Mt Wilhelm, New Guinea the mean daily temperature is $11.6^{\circ} \mathrm{C}$, mean minimum of $4^{\circ} \mathrm{C}$,

220 absolute maximum of $16.7^{\circ} \mathrm{C}$, absolute minimum of $-0.8^{\circ} \mathrm{C}$, and precipitation of some $3450 \mathrm{~mm}$

221 per year (Corlett 1984), though it is expected that the microclimate on the sub-alpine forest floor

222 would be milder. The climate at Pindaunde has been described as "wintery at night, (and) has

223 days which seem to belong to a chilly spring or autumn" (McVean 1968). Were P. manokwari 
224 introduced to temperate countries and escape hothouse or similar containment, the flatworm may

225 well survive winters and become established. High frequencies of warm winters in temperate

226 zones may also facilitate the establishment of the flatworm in these places (Sugiura 2009). The

227 flatworm has survived in the hothouse at Caen, and it is expected that it would also survive

228 outdoors in this region, and even more easily in more southern part of Europe. An assessment of

229 the global potential distribution of Platydemus manokwari, based on ecoclimatic data has not yet 230 been undertaken.

231 Prey

232 Terrestrial molluscs form the principal prey upon which Platydemus manokwari has been

233 observed to feed in the field (Table 2) and under laboratory and experimental conditions (Table

234 3), though the flatworm will also feed upon other soil-dwelling invertebrates including annelids,

235 arthropods, nemerteans, and flatworms (Tables 2 and 3). The flatworm does not appear to be

236 cannibalistic (Kaneda et al. 1990; Ohbayashi et al. 2005; Sugiura 2010).

237 A number of species of terrestrial flatworms will, when moisture conditions are right, seek

238 prey above the ground. Platydemus manokwari has been observed feeding on both juvenile and

239 adult partulid snails at heights above one metre in trees, and in captivity the flatworm fed on

240 specimens of Partula sp. and Pythia sp. (Eldredge \& Smith 1995; Hopper \& Smith 1992).

241 Experimentally, P. manokwari has been shown to track artificially created snail scent trails on the

242 ground (Iwai et al. 2010), and up trees, supporting the hypothesis that the introduction of $P$.

243 manokwari is an important cause in the rapid decline or extinction of native arboreal snails as

244 well as ground-dwelling snails on Pacific Islands (Sugiura \& Yamaura 2008).

245 Where there are sufficient individuals of $P$. manokwari following sensory cues of the

246 same prey the flatworms can overwhelm their prey by sheer numbers in a gregarious or "gang"

247 attack (Mead 1963; Ohbayashi et al. 2005; Sugiura 2010).

248 Waterhouse and Norris (1987) considered that P. manokwari appeared to be an

249 opportunistic carnivore and generally unselective in the choice of prey. Success of Platydemus

250 manokwari as a biological control agent for Achatina fulica can be attributed to its polyphagy,

251 resistance to starvation, ability to survive and reproduce on alternative prey and potential to

252 reproduce rapidly in synchrony with prey populations (Winsor et al. 2004).

253 Invasion of a site by Platydemus manokwari may directly and indirectly impact on native

254 and introduced arboreal, terrestrial soil and to a much lesser extent semi-aquatic slow-moving

255 invertebrate fauna. 


\section{Impacts}

257 From an agricultural perspective Platydemus manokwari is not a direct plant pest. In fact it has

258 been and probably will continue to be used by local farmers, and plant protection agencies in the

259 Pacific region as a Bio-agent in the control of outbreaks of the Giant African snail Achatina

260 fulica (FAO-SAPA 2002; Winsor et al. 2004), though other factors apart from flatworm predation

261 may contribute to the decline in pest snail populations (Lydeard et al. 2004).

262

Examined from an environmental perspective $P$. manokwari has demonstrably had a

263 serious negative impact on the biodiversity of native snail populations in the Pacific region

264 (Cowie 2010) and wherever it is deliberately or accidentally introduced it will continue to pose a 265 threat not only to native molluscs, but possibly to other slow-moving soil invertebrates (Sugiura

266 2010). It may also indirectly have a negative impact on vertebrate species dependent upon these 267 soil invertebrates.

268 An environmental pest risk assessment along the lines of that in the International

269 Standards for Phytosanitary Measures (IPPC 2004) may need to be undertaken for P. manokwari:

270 an assessment of the probability of direct spread of the flatworm, considered by us to be low;

271 whether the population is actively reproducing and is viable; an assessment of economic

272 consequences, for example potential threats to commercial snail farming; and environmental

273 consequences, for example negative impacts on soil invertebrate biodiversity in France and

274 elsewhere. The extent of this incursion, and whether or not it is limited to the hothouse in Caen,

275 the likely primary dispersal source of the current incursion, and possible secondary dispersal

276 through plant exchanges between botanic gardens, and garden centres or plant supermarkets

277 should also be considered.

\section{Possible control options}

279 As it is not a plant pest Platydemus manokwari is not listed in the European and Mediterranean

280 Plant Organization A1 or A2 List of pests recommended for regulation as quarantine pests (EPPO

281 2013a, b), nor listed by the European Alien Species Information Network (EASIN 2014). In

282 Europe countries participating in the NOBANIS network have established a simple early warning 283 system (Secretariat of NOBANIS 2012). When a participating country becomes aware that a new 284 alien species has been found in their country, a warning is sent to the other participating countries 285 and posted on the NOBANIS website. This early warning enables countries to be alerted that a 286 new species has been observed in the region. 
Depending upon the outcome of an environmental risk assessment and related

288

289

290

291

292

293

294

295

296

297

298

299

300

301

302

303

304

305

306

307

308

309

310

311

312

313

314

315

316

317

318

investigations, threats from Platydemus manokwari may need to be responded to in a similar manner to the invasive New Zealand flatworm Arthurdendyus triangulatus. This species is now subject to an EPPO Standard regarding import requirements (EPPO 2000a) and nursery inspection, exclusion and treatment (EPPO 2000b) for the flatworm (Murchie 2010). The problem with $P$. manokwari is that even though it is primarily an environmental threat, it does not 'indirectly affect plants through the effects on other organisms". Consequently there is the possibility that responsibility for managing this invasive species may fall between the remits of agricultural and environmental regulatory bodies. This could delay effective management of $P$. manokwari.

\section{Chemical control}

Although a range of commercial pesticides were tested against Arthurdendyus triangulatus only gamma-HCH (Lindane), a broad spectrum, organochlorine insecticide gave significant control but was considered unsuitable for the widespread control of the flatworm (Cannon et al. 1999). There may be limited scope for the use of chemicals within an integrated approach to control of invasive alien flatworms combining chemical, physical and cultural methods (Blackshaw 1996; Cannon et al. 1999).

\section{Plant sanitization}

Heat or hot water treatment of containerised plants that would kill invasive alien species has been investigated for Arthurdendyus triangulatus and Platydemus manokwari. Specimens of $A$. triangulatus were killed after immersion in a vial for 5 minutes in water at a temperature of $34^{\circ} \mathrm{C}$ (Murchie \& Moore 1998). This method showed great promise (Cannon et al. 1999) but it does not appear to have been used extensively; rather, the current advice to some amateur composters who had flatworm infestation was to place their compost in glasshouses to get the temperatures as high as possible before disseminating the compost (Murchie, pers. com). Similar experiments were undertaken on four invertebrate soil taxa that included Platydemus manokwari, using immersion in hot water at higher temperatures (Sugiura 2008). It was found that exposure of the animals to hot water at $\geq 43^{\circ} \mathrm{C}$ to $50^{\circ} \mathrm{C}$ for 5 minutes resulted in $100 \%$ mortality for all species tested. In both sets of experiments the flatworms were tested in plastic vials. The ability of the hot water treatment to kill animals in potted soil masses was not examined. Depending upon its porosity and wetting ability the soil may act as a thermal buffer. A more promising method of 
319 hot-water treatment is the drenching method of Tsang (2001) developed to sanitise potted plants

320 of burrowing nematodes and potential other pest species. The treatment in which potted plants

321 were drenched with hot water at $50^{\circ} \mathrm{C}$ for $15-20$ minutes was more effective at killing burrowing

322 nematodes than dipping potted plants in hot water for the same temperature-time regime. Based

323 upon Sugiura's (2008) data the temperature-time regime of the hot-water drench would kill

324 Platydemus manokwari. The drench apparatus may be amenable to commercial development and 325 use.

\section{Biological control}

As yet there are no known specific biological control methods for Platydemus manokwari.

328 Terrestrial flatworms are considered to be top-level predators in the soil ecosystem (Sluys 1999).

329 Although nothing appears to be known about natural enemies of Platydemus manokwari,

330 examples of predation on other species of land planarians by soil and associated fauna are known,

331 mostly under laboratory conditions. They include an instance of predation of the Neotropical

332 species Obama trigueira (E.M. Froehlich, 1955) by Enterosyringia pseudorhynchodemus

333 (Riester, 1938) (Froehlich 1956), and predation of five species of land planarians by $P$.

334 manokwari (Ohbayashi et al. 2005). A chance field observation led to laboratory findings that

335 Arthurdendyus triangulatus was eaten by larvae and adults of species of a carabid and a

336 staphylinid beetles (Gibson et al. 1997).

337 In a series of trials by Lemos et al. (2012) the native Neotropical carnivorous mollusc

338 Rectartemon depressus (Heynemann, 1868) was found to successfully predate upon specimens of

339 at least 10 species of geoplanid terrestrial flatworms as well as five undescribed species of

340 Geoplana, and also the introduced species Bipalium kewense. Whether other species of

341 carnivorous molluscs successfully predate upon flatworms is not yet known. Platydemus

342 manokwari predates upon at least two species of carnivorous molluscs observed in the field

343 (Ohbayashi et al. 2005): the Rosy Wolf snail Euglandina rosea (de Férussac, 1821) and Gonaxis

344 quadrilateralis (Preston, 1901); both these mollusc species were introduced in an attempt to

345 control the Giant African snail Achatina fulica in the Pacific region (Davies and Butler 1964;

346 Lydeard et al. 2004).

$347 \quad$ Platydemus manokwari has a most unpleasant astringent taste (LW pers. obs.), just as has

348 been noted for other species (Dendy 1891). Bellwood (pers. comm. to LW, 13.11.1997) in his

349 private urban garden, remarked that free-range domestic bantams that noticed P. manokwari on

350 an upturned log pecked at, took the flatworms into their mouths, then immediately rejected them; 
351 when at a much later time $P$. manokwari was subsequently noticed by the bantams they refused to

352 peck at the flatworms. This is similar to behaviour of domestic fowls offered Caenoplana

353 spenceri (Dendy 1891). Predation of flatworms by native species of birds has not been reported.

354 Predation of terrestrial flatworms by herpetofauna has also been investigated. The

355 flatworm Bipalium adventitium Hyman, 1943, invasive in North America, was offered by Ducey

356 et al. (1999) to six species of salamanders and two species of snakes; none of the herpetofaunal

357 species tested treated Bipalium adventitium as a potential prey item.

358 Parasitization of P. manokwari by nematodes, gregarines or mycetophilid flies, known in

359 other species of land planarians (Graff 1899; Hickman 1964), has not yet been observed.

360

Lemos et al. (2012) advocate further experimental testing of other potential invertebrate

361 and vertebrate predators of flatworms in an attempt to better understand predator-prey

362 relationships, and cognisant of the risks associated with biological control, they consider the use

363 of non-indigenous species should be avoided, and when necessary be based upon accurate pre-

364 release testing and post-release monitoring.

\section{Conclusion}

366 The serious negative environmental impacts of Platydemus manokwari on the biodiversity of 367 native land snails in the Indo-Pacific are well documented. The risks posed by the incursion of 368 this species in France have not yet been assessed. The European Union has recently proposed 369 new legislation to prevent and manage the rapidly growing threat to biodiversity from invasive 370 species (European Commission 2013). The proposal centres on a list of invasive alien species of 371 concern for Europe, which will be drawn up with the Member States using risk assessments and 372 scientific evidence. Whether or not Platydemus manokwari will be included on this list remains 373 to be seen.

\section{Acknowledgements}

375 The authors are grateful to Gerard Peaucellier and Mrs J. Vivant for providing information on

376 terrestrial flatworms in France, to David Bellwood in Townsville, Queensland for his

377 observations on the feeding response of domestic bantams to P. manokwari, to Gilianne Brodie,

378 School of Biological and Chemical Sciences, University of the South Pacific, Fiji, for her papers

379 on the occurrence of Platydemus manokwari at Rotuma, to Archie Murchie, Agri-Food and

380 Biosciences Institute, Belfast, Northern Ireland, for information and advice on current plant 
381 sanitation practices, standards and legislation for the Invasive Alien Species Arthurdendyus

382 triangulatus, to Nicolas Puillandre (MNHN, Paris) for help with the sequences, to Pierre Lozouet

383 (MNHN, Paris) who identified the prey snail. We are especially thankful to Damien Loisel and

384 David Philippart (FREDON Basse-Normandie, France) and Martine Aires (DRAAF Basse-

385 Normandie, France) for collection of specimens and administrative support, and to Damien

386 L'Hours and Nelly Hubert (Ville de Caen, France) for allowing collection in the hothouse in Caen

387 and providing administrative support. Hugh Jones, Ana M. Leal-Zanchet, Fernando Carbayo and

388 Maria Riutort are acknowledged for their constructive comments on an earlier version of this

389 paper. 
391

392

393

394

395

396

397

398

399

400

401

402

403

404

405

406

407

408

409

410

411

412

413

414

415

416

417

418

419

420

421

422

423

424

425

426

Alford DV, Lole MJ, and Emmett BJ. 1996. Alien terrestrial planarians in England and Wales, and implications for horticultural trade. Brighton crop protection conference: pests \& diseases - 1996: volume 3: Proceedings of an international conference, Brighton, UK, 1821 November 1996, 1083-1088.

Alvarez-Presas M, Mateos E, Vila-Farré M, Sluys R, and Riutort M. 2012. Evidence for the persistence of the land planarian species Microplana terrestris (Müller, 1774) (Platyhelminthes, Tricladida) in microrefugia during the Last Glacial Maximum in the northern section of the Iberian Peninsula. Molecular Phylogenetics and Evolution 64:491499.

Bauman S. 1996. Diversity and decline of land snails on Rota, Mariana Islands. American Malacological Bulletin 12:13-27.

Blackshaw RP. 1996. Control options for the New Zealand flatworm. Brighton Crop Protection Conference - Pests and Diseases. Volume III, pp. 1089-1094.

Boag B, Palmer LF, Neilson R, and Chambers SJ. 1994. Distribution and prevalence of the predatory planarian Artioposthia triangulata (Dendy) (Tricladida: Terricola) in Scotland. Annals of Applied Biology 124:165-171.

Boag B, and Yeates GW. 2001. The potential impact of the New Zealand flatworm, a predator of earthworms, in Western Europe. Ecological Applications 11:1276-1286.

Breugelmans K, Quintana Cardona J, Artois T, Jordaens K, and Backeljau T. 2012. First report of the exotic blue land planarian, Caenoplana coerulea (Platyhelminthes, Geoplanidae), on Menorca (Balearic Islands, Spain). Zookeys 199:91-105.

Brodie G, Barker GM, Stevens F, and Fiu M. 2013. Preliminary re-survey of the land snail fauna of Rotuma: conservation and biosecurity implications. Pacific Conservation Biology 20:in press.

Brodie G, Stevens F, and Barker G. 2012. Report on a preliminary survey of the land snail fauna of Rotuma. http://www.rotuma.net/os/Publications/land snail_survey.pdf

Cannon RJC, Baker RHA, Taylor MC, and Moore JP. 1999. A review of the status of the New Zealand flatworm in the UK. Annals of Applied Biology 135:597-614.

Christensen OM, and Mather JG. 1998. The 'New Zealand flatworm', Artioposthia triangulata, in Europe: the Faroese situation. Pedobiologia 42 532-540.

Convention on Biological Diversity. 2009. What are Invasive Alien Species? http://www.cbd.int/idb/2009/about/what/default.shtml (accessed 06-Fev-2014).

Corlett RT. 1984. Human impact on the subalpine vegetation of Mt Wilhelm, Papua New Guinea. Journal of Ecology 72:841-854.

Cowie RH, and Robinson AC. 2003. The decline of native Pacific island faunas: changes in status of the land snails of Samoa through the 20th century. Biological Conservation 110:55-65. 
Cowie RHC. 2010. Platydemus manokwari (flatworm) profile. In: Global Invasive Species Database. http://www.issg.org/database/welcome. Accessed 09/11/2013.

Davis CJ, and Butler GD. 1964. Introduced enemies of the Giant African snail, Achatina fulica Bowdich, in Hawaii (Pulmonata: Achatinidae). Proceedings of the Hawaiian Entomological Society 18: 377-390.

de Beauchamp P. 1962. Platydemus manokwari n. sp., planaire terrestre de la Nouvelle-Guinée Hollandaise. Bulletin de la Société Zoologique de France 87:609-615.

de Beauchamp P. 1972. Planaires terrestres de Nouvelle-Guinée. Cahiers du Pacifique 16:181192.

Dendy A. 1891. The Victorian land planarians. Transactions of the Royal Society of Victoria 2 (for 1890): 65-80.

Ducey PK, Messere M, Lapoint K, and Noce S. 1999. Lumbricid prey and potential herpetofaunal predators of the invading terrestrial flatworm Bipalium adventitium (Turbellaria: Tricladida: Terricola). American Midland Naturalist 141: 305-314.

Ducey PK. McCormick M, and Davidson E. 2007. Natural history observations on Bipalium cf. vagum Jones and Sterrer (Platyhelminthes: Tricladida), a terrestrial broadhead planarian new to North America. Southeastern Naturalist 6: 449-460.

Ducey PK, West L-J, Shaw G, and De Lisle J. 2005. Reproductive ecology and evolution in the invasive terrestrial planarian Bipalium adventitium across North America. Pedobiologia 49: 367-377.

Eldredge LG, and Smith BD. 1995. Triclad flatworm tours the Pacific. Aliens 2:11.

EASIN (European Alien Species Information Network). 2014 Terrestrial alien species in europe. http://easin.jrc.ec.europa.eu

EPPO (European and Mediterranean Plant Protection Organization). 2000a. EPPO Standards. Guidelines on Arthurdendyus triangulatus. Import requirements concerning Arthurdendyus triangulatus. http://archives.eppo.int/EPPOStandards/PM1 GENERAL/pm1-03-e.doc

EPPO (European and Mediterranean Plant Protection Organization). 2000b. Guidelines on Arthurdendyus triangulatus. Import requirements concerning Arthurdendyus triangulatus. http://archives.eppo.int/EPPOStandards/PM1 GENERAL/pm1-03-e.doc.

EPPO (European and Mediterranean Plant Protection Organization). 2013a. EPPO A1 List of pests recommended for regulation as quarantine pests (version 2013-09). http://www.eppo.int/QUARANTINE/listA1.htm

EPPO (European and Mediterranean Plant Protection Organization). 2013b. EPPO A2 List of pests recommended for regulation as quarantine pests (version 2013-09). http://www.eppo.int/QUARANTINE/listA2.htm

European Commission. 2013 Press release 09/09/2013. Environment: New EU Action to protect biodiversity against problematic invasive species. http://europa.eu/rapid/press-release IP13-818 en.htm

Filella-Subirá E (1983) Nota sobre la presència de la planària terrestre Bipalium kewense Mosoley [sic], 1878 a Catalunya. Butlleti de la Institució Catalana d'Història Natural 49: 151. 
469

470

471

472

473

474

475

476

477

478

479

480

481

482

483

484

485

486

487

488

489

490

491

492

493

494

495

496

497

498

499

500

501

502

503

504

505

506

507
FAO-SAPA (Food and Agriculture Organization Sub-regional officer for the Pacific Islands). 2002. Bio-control: flatworms and nemertean worms collected and identified from Cook Islands, Niue, Tonga and Vanuatu. SAPA Newsletter 6:3.

Froehlich CG. 1956. On the biology of land planarians. Boletim da Faculdade de filosofia, ciéncias e letras, Universidade de São Paulo 20: 263-272.

Gasiglia S. 2013. À Cagnes, alerte au ver plat mangeur de lombrics. Nice-Matin. Nice. June 2, 2013, page 8.

Gibson PH, Cosens D, and Buchanan K. 1997. A chance field observation and pilot laboratory studies of predation of the New Zealand flatworm by the larvae and adults of carabid and staphylinid beetles. Annals of Applied Biology 130: 581-585.

Graff L von. 1899. Monographie der Turbellaria. II Tricladida Terricola (Landplanarien). Text \& Atlas. Wilhelm Engelmann: Leipzig.

Groult J-M, and Boucourt F. 2014. Les vers exotiques menacent nos lombrics. Mon Jardin \& Ma Maison. $N^{\circ}$ 648, January 2014, pages 100-101.

Guyon J. 2014. Le ver tueur de lombrics est entré dans Paris. Le Parisien. Paris. January 5, 2014, page 14. http://www.leparisien.fr/espace-premium/paris-75/le-ver-tueur-de-lombrics-estentre-dans-paris-05-01-2014-3462717.php

Heyligen J. 2013. Le tueur de lombrics repéré dans le département. Le Parisien, édition Essonne. Paris. October 4, 2013. http://www.leparisien.fr/espace-premium/essonne-91/le-tueur-delombrics-repere-dans-le-departement-04-10-2013-3194081.php

Hickman VV. 1964. On Planarivora insignis Gen. et sp.n. (Diptera; Mycetophilidae), whose larval stages are parasitic in land planarians. Papers and Proceedings of the Royal Society of Tasmania 99: 1-8.

Hopper D. 1990. Threats to Partula on Guam, Mariana Islands. Tentacle 1:3-4.

Hopper DR, and Smith BD. 1992. Status of tree snails (Gastropoda: Partulidae) on Guam, with a resurvey of sites studied by H. E. Crampton in 1920. Pacific Science 46:77-85.

Hyman LH. 1954. Some land planarians of the United States and Europe, with remarks on nomenclature. American Museum Novitates No. 1667: 1-21.

International Commission on Zoological Nomenclature. 1999. International Code of Zoological Nomenclature: The International Trust for Zoological Nomenclature.

IPPC (International Plant Protection Convention). 2004. International Standards for Phytosanitary Measures: Pest risk analysis for quarantine pests, including analysis of environmental risks and living modified organism. International Standards for Phytosanitary Measures No. 11, 117-138.

Iwai N, Sugiura S, and Chiba S. 2010. Prey-tracking behavior in the invasive terrestrial planarian Platydemus manokwari (Platyhelminthes, Tricladida). Naturwissenschaften 97:997-1002.

Jones HD. 1998. The African and European land planarians faunas, with an identification guide for field workers in Europe. Pedobiologia 42:477-489.

Jones HD. 2005. Identification: British land flatworms. British Wildlife 16:189-194. 
508

509

510

511

512

513

514

515

516

517

518

519

520

521

522

523

524

525

526

527

528

529

530

531

532

533

534

535

536

537

538

539

540

541

542

543

544

545

546

547

548

549

550

Jones HD, Santoro G, Boag B, and Neilson ROY. 2001. The diversity of earthworms in 200 Scottish fields and the possible effect of New Zealand land flatworms (Arthurdendyus triangulatus) on earthworm populations. Annals of Applied Biology 139:75-92.

Justine J-L. 2013. Blog: Plathelminthes terrestres invasifs. https://sites.google.com/site/jljjustine/plathelminthe-terrestre-invasif or http://bit.ly/Plathelminthe

Kaneda M, Kitagawa K, and Ichinohe F. 1990. Laboratory rearing method and biology of Platydemus manokwari de Beauchamp (Tricladida: Terricola: Rhynchodemidae). Applied Entomology and Zoology 25:524-528.

Kaneda M, Kitagawa K, Nagai H, and Ichinohe F. 1992. The effects of temperature and prey species on the development and fecundity of Platydemus manokwari de Beauchamp (Tricladida: Terricola: Rhynchodemidae). Research Bulletin of Plant Protection Series of Japan 28:7-11.

Kawakatsu M, and Ogren RE. 1994. A preliminary report on land planarians from the Northern Mariana Islands (Turbellaria, Tricladida, Terricola). Natural History Research Special Issue 1:107-112.

Kawakatsu M, Ogren RE, Froehlich EM, Takai M, and Sasaki G-Y. 2002. Additions and corrections of the previous land planarians indicies of the world (Turbellaria, Seriata, Tricladida, Terricola). Additions and corrections of the previous land planarians indicies of the world-10. Bulletin of the Fuji Women's College No. 40:162-177.

Kawakatsu M, Ogren RE, and Muniappan R. 1992. Redescription of Platydemus manokwari de Beauchamp, 1962 (Turbellaria: Tricladida: Terricola), from Guam and the Philippines. Proceedings of the Japanese Society of Systematic Zoology 47:11-25.

Kawakatsu M, Oki I, Tamura S, Itô, Nagai Y, Ogura K, Shimabukuro S, Ichinohe F, Katsumata H, and Kaneda M. 1993. An extensive occurrence of a land planarian, Platydemus manokwari de Beauchamp, 1962, in the Ryûkuû Islands, Japan (Turbellaria, Tricladida, Terricola). Biology of Inland Waters 8:5-14.

Kawakatsu M, Okochi K, Sato H, Okochi K, Ohbayashi T, Kitagawa K, and Totani K. 1999. A preliminary report on land planarians (Turbellaria, Seriata, Tricladida, Terricola) and land nemertine (Enopla, Hoplonemertea, Monostylifera) from the Ogasawara Islands. Occasional Publications, Biological Laboratory of Fuji Women's College, Sapporo (Hokkaidô) 32:1-8.

Lemos VS, Canello R, and Leal-Zanchet AM. 2012. Carnivore mollusks as natural enemies of invasive land flatworms. Annals of Applied Biology 161:127-131.

Littlewood DTJ, Rohde K, and Clough KA. 1997. Parasite speciation within or between host species? - Phylogenetic evidence from site-specific polystome monogeneans. International Journal for Parasitology 27:1289-1297.

Lovenburg V. 2009. Terrestrial gastropod distributional factors: native and nonnative forests, elevation and predation on Mo'orea, French Polynesia. UC Berkeley: UCB Moorea Class: Biology and Geomorphology of Tropical Islands. http://www.escholarship.org/uc/item/73t4j6xs

Lowe S, Browne M, Boudjelas S, and De Poorter M. 2000. 100 of the World's Worst Invasive Alien Species. A selection from the Global Invasive Species Database. Published by The 
551

552

553

554

555

556

557

558

559

560

561

562

563

564

565

566

567

568

569

570

571

572

573

574

575

576

577

578

579

580

581

582

583

584

585

586

587

588

589

590

591

Invasive Species Specialist Group (ISSG) a specialist group of the Species Survival Commission (SSC) of the World Conservation Union (IUCN), 12pp. First published as special lift-out in Aliens 12, December 2000. Updated and reprinted version: November 2004.

Lydeard C, Cowie RH, Ponder WF, Bogan AE, Bouchet P, Clark SA, Cummings KS, Frest TJ, Gargominy O, Herbert DG et al.2004. The global decline of nonmarine mollusks. Bioscience 54:321-330.

Mateos, E., Tudo, A., Alvarez-Presas, M. \& Riutort, M. 2013: Planàries terrestres exòtiques a la Garrotxa. Annals de la Delegació de la Garrotxa de la Institució Catalana d'Historia Natural $6: 67-73$.

McVean DN. 1968. A year of weather records at 3480m on Mt Wilhelm, New Guinea. Weather 23:377-381.

Mead AR. 1963. A flatworm predator of the giant African snail Achatina fulica in Hawaii. Malacologia 1:305-311.

Mead AR. 1979. Economic malacology with particular reference to Achatina fulica. In: Fretter V, and Peaks J, eds. Pulmonates, Vol 2B. London: Academic Press.

Moore JP, Dynes C, and Murchie AK. 1998. Status and public perception of the "New Zealand flatworm", Artioposthia triangulata (Dendy), in Northern Ireland. Pedobiologia 42:563571.

Muniappan R. 1987. Biological control of the giant African snail, Achatina fulica Bowdich, in the Maldives. FAO Plant Protection Bulletin 35:127-133.

Muniappan R, Duhamel G, Santiago RM, and Acay DR. 1986. Giant African snail control in Bugsuk island, Philippines, by Platydemus manokwari. Oléagineux 41:183-186.

Murchie AK. 2010. Between two stools: dealing with the problem of the New Zealand flatworm. Aspects of Applied Biology 104:73-78.

Murchie AK, and Gordon AW. 2013. The impact of the "New Zealand flatworm", Arthurdendyus triangulatus, on earthworm populations in the field. Biological Invasions 15:569-586.

Murchie AK, and Moore JP. 1998. Hot-water treatment to prevent transference of the "New Zealand flatworm", Artioposthia triangulata. Pedobiologia 42:572.

Ogren RE, Kawakatsu M, and Froehlich EM. 1997. Additions and corrections of the previous land planarian indicies of the world (Turbellaria: Tricladida: Terricola). Addendum IV. Geographic locus index: Bipaliidae; Rhynchodemidae (Rhynchodeminae; Microplaninae); Geoplanidae (Geoplaninae; Caenoplaninae; Pelmatoplaninae). Bulletin of the Fuji Women's College (Series 2) 35:63-103.

Ohbayashi T, Okochi I, Sato H, and Ono T. 2005. Food habit of Platydemus manokwari De Beauchamp, 1962 (Tricladida: Terricola: Rhynchodemidae), known as a predatory flkatworm of land snails in the Ogasawara Islands, Japan. Japanese Journal of Applied Entomology and Zoology 40:609-614.

Placé J-M. 2013. Apparition d'une espèce de plathelminthe dans les sols de l'Essonne. Question écrite $\mathrm{n}^{\circ} 09593$ de M. Jean-Vincent Placé, publiée dans le Journal Officiel du Sénat du 05/12/2013 - page 3466. http://www.senat.fr/questions/base/2013/qSEQ131209593.html. 
592

593

594

595

596

597

598

599

600

601

602

603

604

605

606

607

608

609

610

611

612

613

614

615

616

617

618

619

620

621

622

623

624

625

626

627

628

629

630

631

632

Purea M, Matalavea S, Bourke T, and Hunter D. 1998. Platydemus manokwari de Beauchamp, a flatworm predator of the giant African snail (Achatina fulica Bowdich) recorded in Samoa. Journal of South Pacific Agriculture 5:71-72.

Raut SK, and Barker GM. 2002. Achatina fulica Bowdich and other Achatinidae as pests in tropical agriculture. In: Barker GM, ed. Molluscs as Crop Pests. Wallingford, U.K. : CAB International, 54-114.

Remy P. 1942 Quelques Arthropodes intéressants des serres du Parc de la Tête d'Or. Bulletin Mensuel de la Société Linnéenne de Lyon 9:140-142.

Santoro G, and Jones HD. 2001. Comparison of the earthworm population of a garden infested with the Australian land flatworm (Australoplana sanguinea alba) with that of a noninfested garden. Pedobiologia 45:313-328.

Schreurs J. 1963. Investigations on the biology, ecology and control of the giant African snail in west New Guinea. Unpublished report, Manokwari Agricultural Research Station.

Secretariat of NOBANIS. 2012. Riskmapping for 100 nonnative species in Europe. http://www.nobanis.org/files/Riskmapping_report.pdf . Copenhagen: NOBANIS European Network on Invasive Alien Species.

Simberloff D. 2014. Biological invasions: What's worth fighting and what can be won? Ecological Engineering. doi: 10.1016/j.ecoleng.2013.08.004

Sluys R. 1999. Global diversity of land planarians (Platyhelminthes, Tricladida, Terricola): a new indicator-taxon in biodiversity and conservation studies. Biodiversity and Conservation 8: 1663-1681.

Sugiura S. 2008. Hot water tolerance of soil animals : utility of hot water immersion in preventing invasions of alien soil animals. Applied Entomology and Zoology 43:207-212.

Sugiura S. 2009. Seasonal fluctuation of invasive flatworm predation pressure on land snails: Implications for the range expansion and impacts of invasive species. Biological Conservation 142:3013-3019.

Sugiura S. 2010. Prey preference and gregarious attacks by the invasive flatworm Platydemus manokwari. Biological Invasions 12:1499-1507.

Sugiura S, and Yamaura Y. 2008 Potential impacts of the invasive flatworm Platydemus manokwari on arboreal snails. Biological Invasions 11:737-742.

Tamura K, Peterson D, Peterson N, Stecher G, Nei M, and Kumar S. 2011. MEGA5: Molecular evolutionary genetics analysis using maximum likelihood, evolutionary distance, and maximum parsimony methods. Molecular Biology and Evolution 28:2731-2739.

Tsang MMC, Hara AH, and Sipes BS. 2001. A hot water drenching system for disinfesting roots and media of potted plants of the burrowing nematodes. Applied Engineering in Agriculture 17:533-538.

van Driest JT. 1968. Correspondentieblad. Nederlandse Malacologie Vereniging 127:1361-1362.

Vivant J. 2005. Bipalium kewense Moseley, ver tropical terricole, existe à Orthez (Pyr. atl.). Bulletin de la Société Mycologique Landaise 30: 46-48.

Waterhouse DE, and Norris KR. 1987. Biological Control: Pacific prospects. Canberra: Australian Centre for International Agricultural Research. 
633 Winsor L. 1990. Taxonomic studies on free-living flatworms (Turbellaria: Platyhelminthes) of the

634

635

636

637

638

639

640

641 Australian Zoogeographic Region. Chapter 4: Taxonomy and biology of a molluscivorous terrestrial flatworm Platydemus manokwari Beauchamp, 1962. MSc thesis. James Cook University: Townsville.

Winsor L. 1999. The New Guinea flatworm - Platydemus manokwari: predator of land snails. Terrestrial flatworms Infosheet No. 6. James Cook University. Townsville.

Winsor L, Johns PM, and Barker GM. 2004. Terrestrial planarians (Platyhelminthes: Tricladida: Terricola) predaceous on terrestrial gastropods. In: Barker GM, ed. Natural enemies of terrestrial molluscs. Oxfordshire, UK: CAB International, 227-278. 


\section{Table 1 (on next page)}

Platydemus manokwari - Distribution records

Platydemus manokwari has been recorded from more than 15 different territories, in Asia and Oceania; our record in France is the first for Europe. 


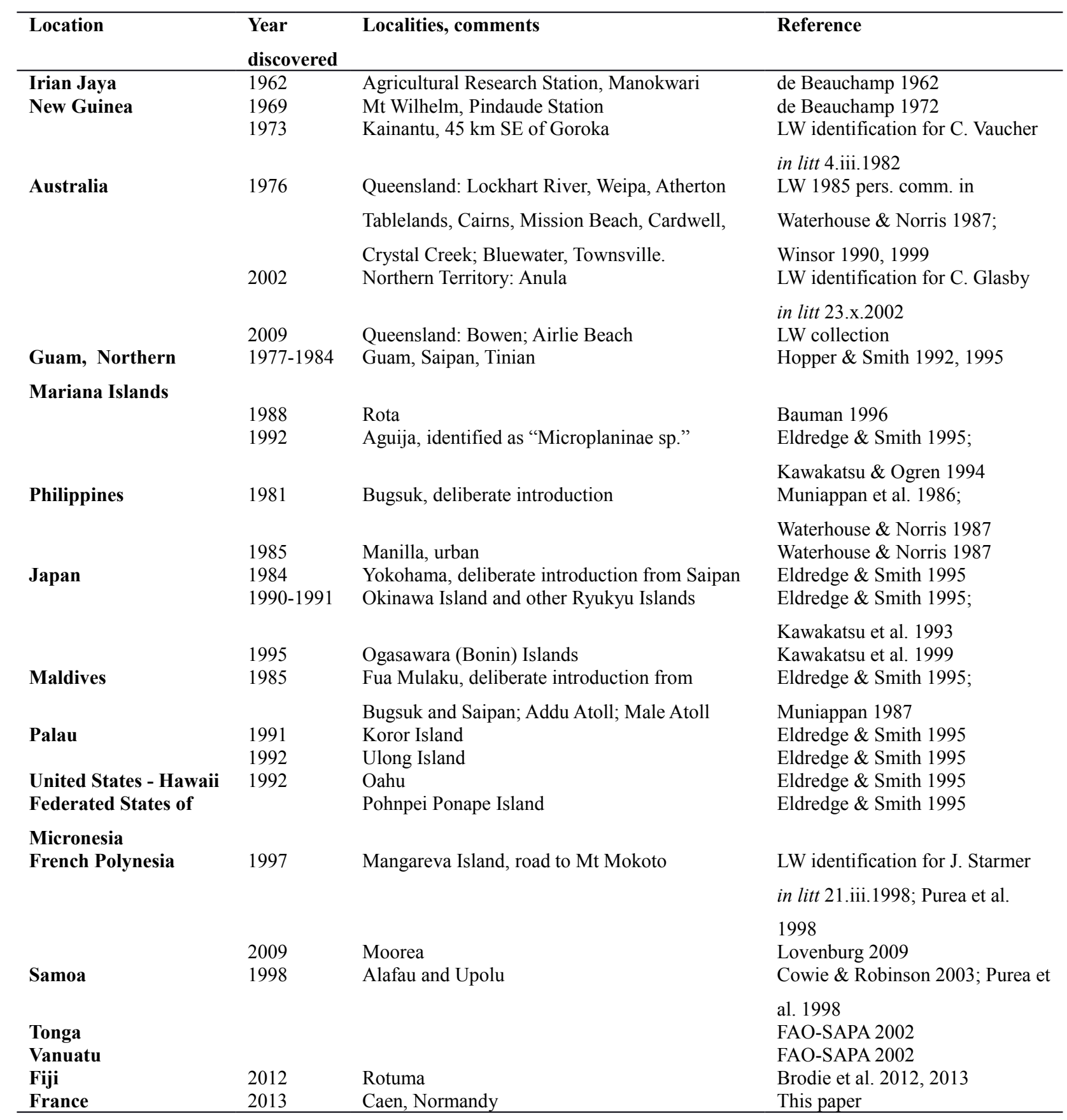




\section{Table 2 (on next page)}

Species reported as prey of Platydemus manokwari, in the field

Platydemus manokwari has been recorded to feed mainly on land gastropod molluscs, and also on earthworms, insects and nemerteans 


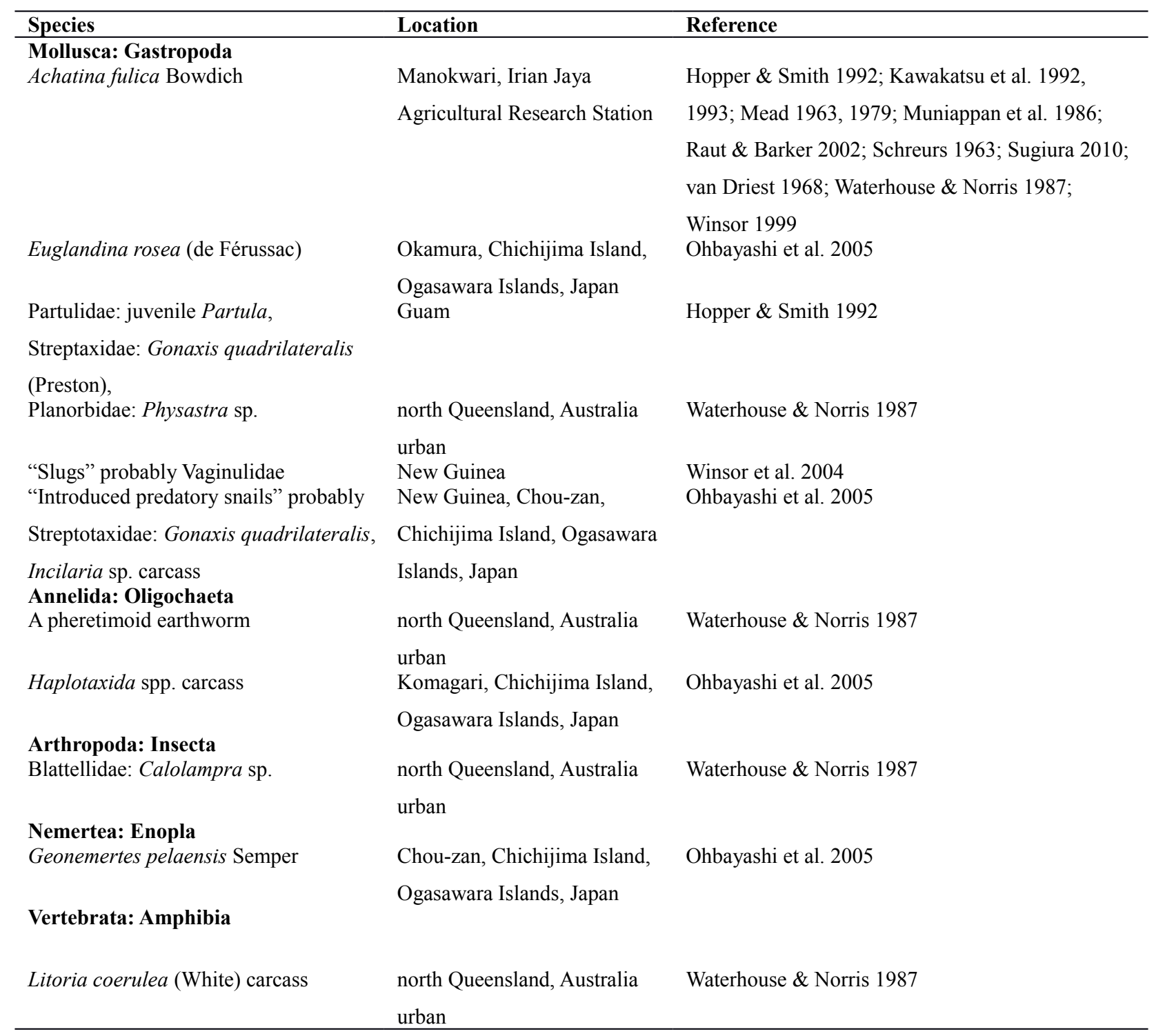




\section{Table 3 (on next page)}

Species reported as prey of Platydemus manokwari, under laboratory conditions

Platydemus manokwari is able to prey on a variety of gastropod molluscs, on nemerteans, earthworms and woodlice, and on other species of land planarians. All reports of prey refer to adults. 


\begin{tabular}{|c|c|}
\hline Species & Reference \\
\hline \multicolumn{2}{|l|}{ Mollusca: Gastropoda } \\
\hline Partula sp. & Hopper 1990 \\
\hline Bradybaenidae: Acusta despecta sieboldiana (Pfeiffer), Bradybaena similaris (de Férussac), & Kaneda et al. 1990, 1992 \\
\hline \multicolumn{2}{|l|}{ Euhadra amaliae callizona (Crosse), Euhadra peliomphala (Pfeiffer), Euhadra quaesita } \\
\hline \multicolumn{2}{|l|}{ (Deshayes), Trishoplita conospira (Pfeiffer); Camaenidae: Satsuma japonica (Pfeiffer); } \\
\hline \multicolumn{2}{|l|}{ Clausiliidae: Euphaedusa tau (Boettger), Pinguiphaedusa hakonensis (Pilsbry), } \\
\hline \multicolumn{2}{|l|}{ Zaptychopsis buschi (Pfeiffer); Discidae: Discus pauper (Gould); Helicarionidae: } \\
\hline \multicolumn{2}{|l|}{ Helicarion sp.; Limacidae: Lehmannia marginata (Müller); Ellobiidae: Pythia scarabaeus } \\
\hline $\begin{array}{l}\text { Linnaeus; Zonitidae: Zonitides arboreus (Say); Achatinidae: Achatina fulica } \\
\text { Achatina fulica, Limax marginatus (Müller), Deroceras laeve (Müller), Euglandina rosea, }\end{array}$ & Ohbayashi et al. 2005 \\
\hline \multicolumn{2}{|l|}{ Bradybaena similaris (de Férussac), Acusta despecta sieboldiana (Pfeiffer) } \\
\hline Acusta despecta (Pfeiffer) & Sugiura 2010 \\
\hline Helicidae: Eobania vermiculata Müller & This paper \\
\hline \multicolumn{2}{|l|}{ Platyhelminthes: Tricladida } \\
\hline $\begin{array}{l}\text { Australopacifica sp., Bipalium kewense, Bipalium sp., Platydemus sp. 1; P. sp. } 2 \\
\text { Nemertea: Enopla }\end{array}$ & Ohbayashi et al. 2005 \\
\hline Geonemertes pelaensis Semper & Ohbayashi et al. 2005 \\
\hline \multicolumn{2}{|l|}{ Annelida: Oligochaeta } \\
\hline Eisenia foetida Savigny & Sugiura 2010 \\
\hline \multicolumn{2}{|l|}{ Arthropoda: Crustacea } \\
\hline Armadillidium vulgare Latreille & Sugiura 2010 \\
\hline
\end{tabular}




\section{Figure 1}

Platydemus manokwari de Beauchamp, 1963.

Specimen collected in a hothouse, Caen, France. Dorsal view: note median longitudinal line.

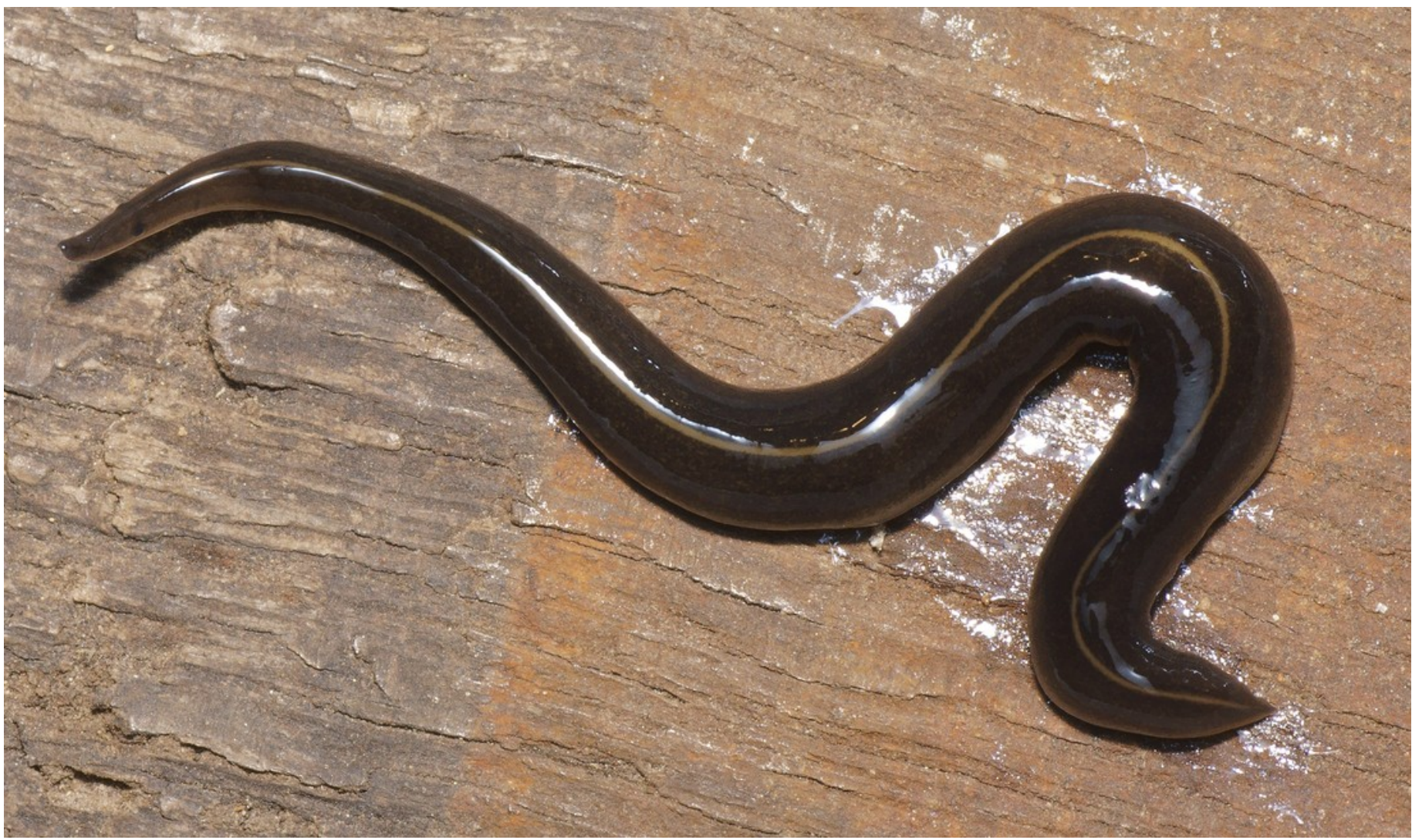




\section{Figure 2}

Platydemus manokwari de Beauchamp, 1963.

Detail of head, lateral view, showing one of the two slightly protuberant eyes.

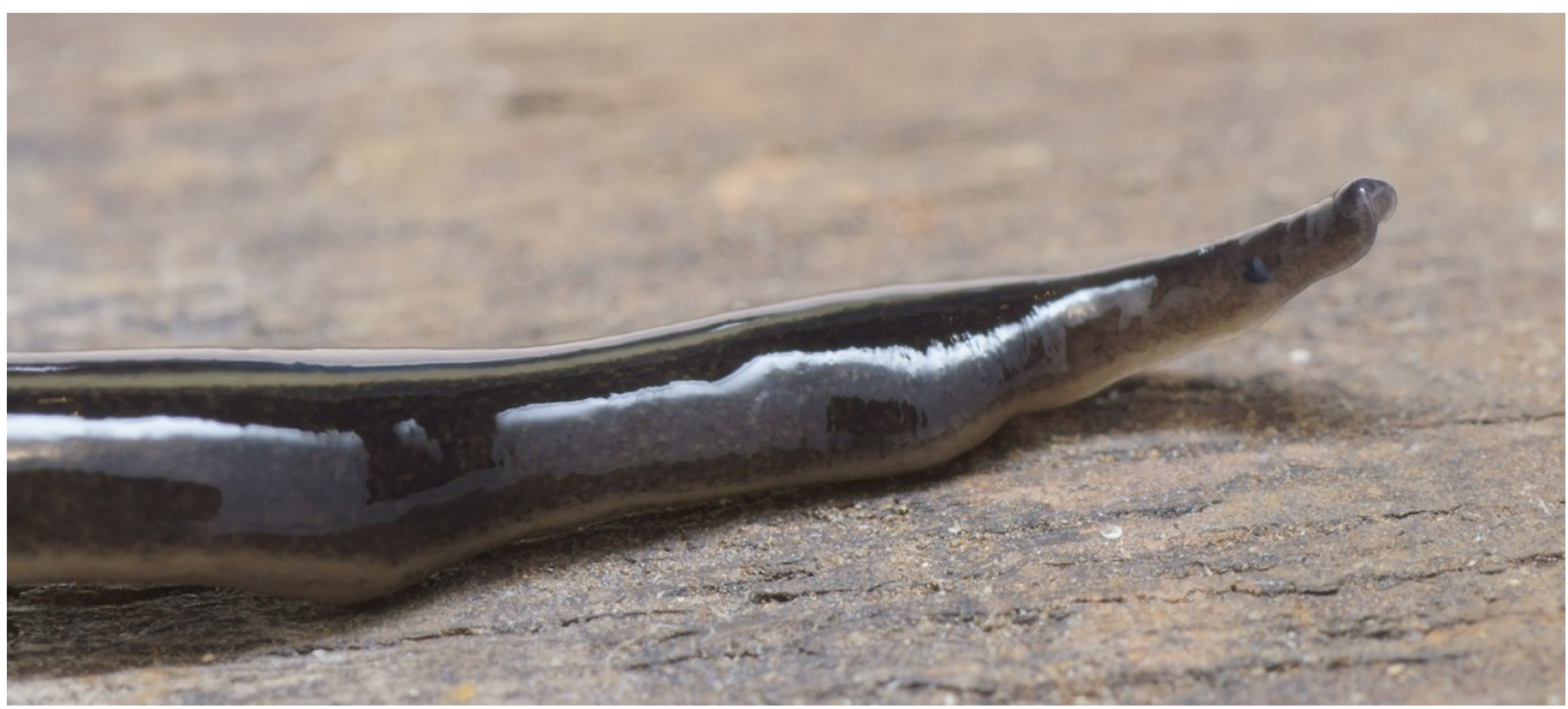




\section{Figure 3}

Platydemus manokwari de Beauchamp, 1963.

Detail of body, dorsal view, showing pale cream median longitudinal stripe on dark olive brown background.

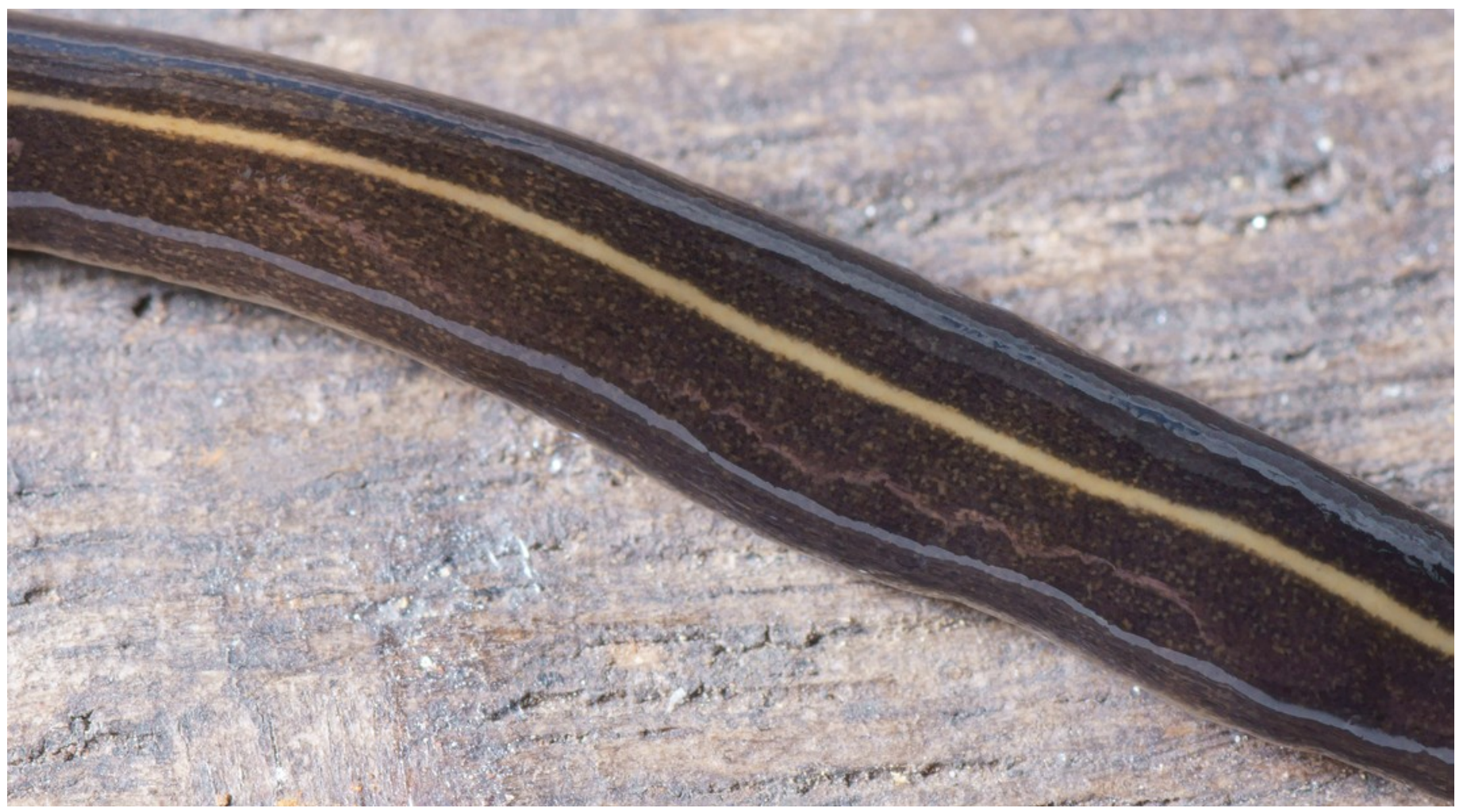




\section{Figure 4}

Platydemus manokwari de Beauchamp, 1963.

Partial ventral view, showing the cream and faint grey marginal stripe, and the creeping sole that is slightly paler along the median line. Scale: millimeters.

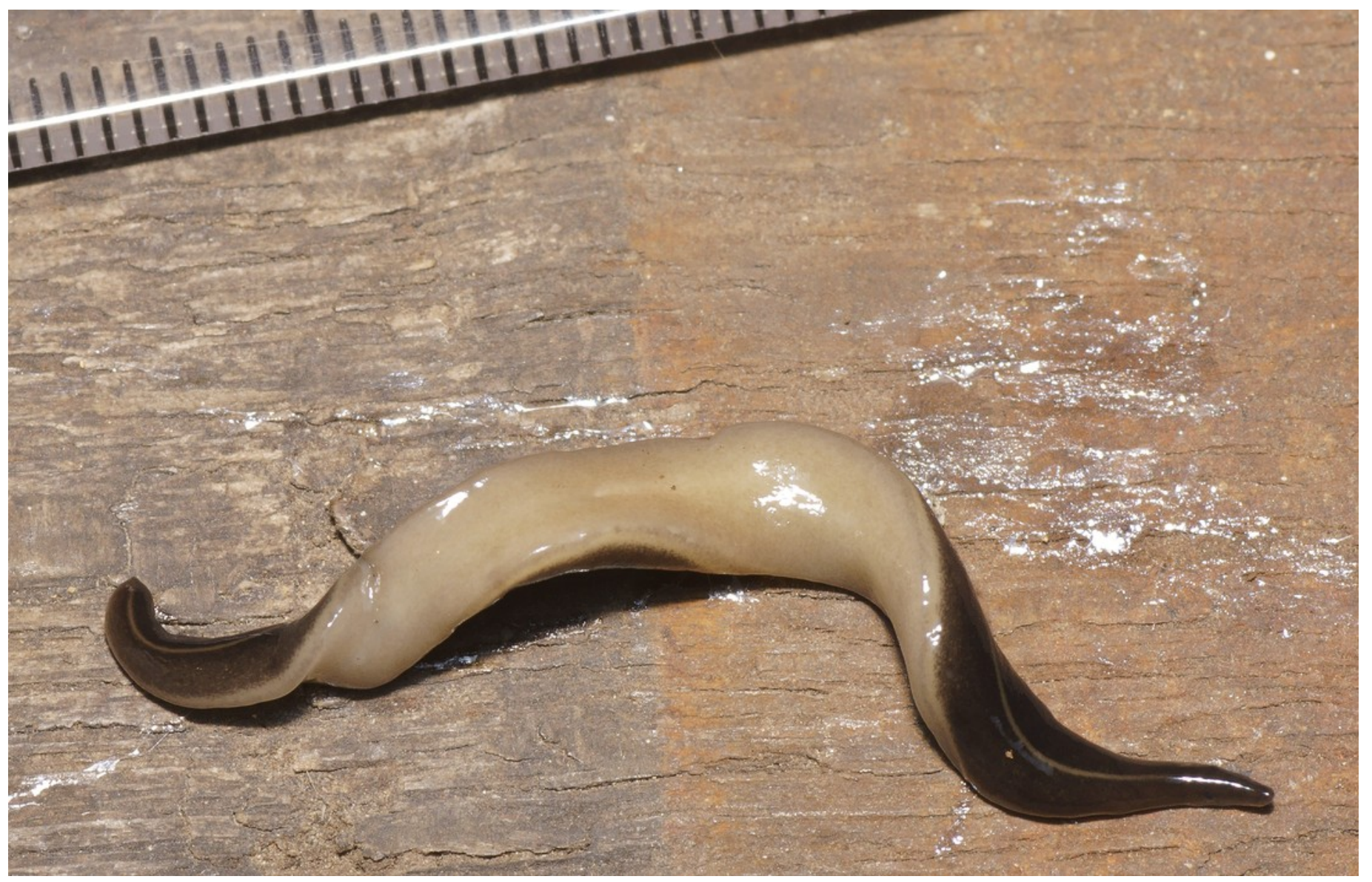




\section{Figure 5}

Platydemus manokwari de Beauchamp, 1963, experimental predation on indigenous snail.

The flatworm is preying on a snail: it has been disturbed, thus showing the white cylindrical pharynx on the ventral side, protruding and ingesting soft tissues of the snail. The prey is the helicid Eobania vermiculata, a common snail of the Mediterranean region.

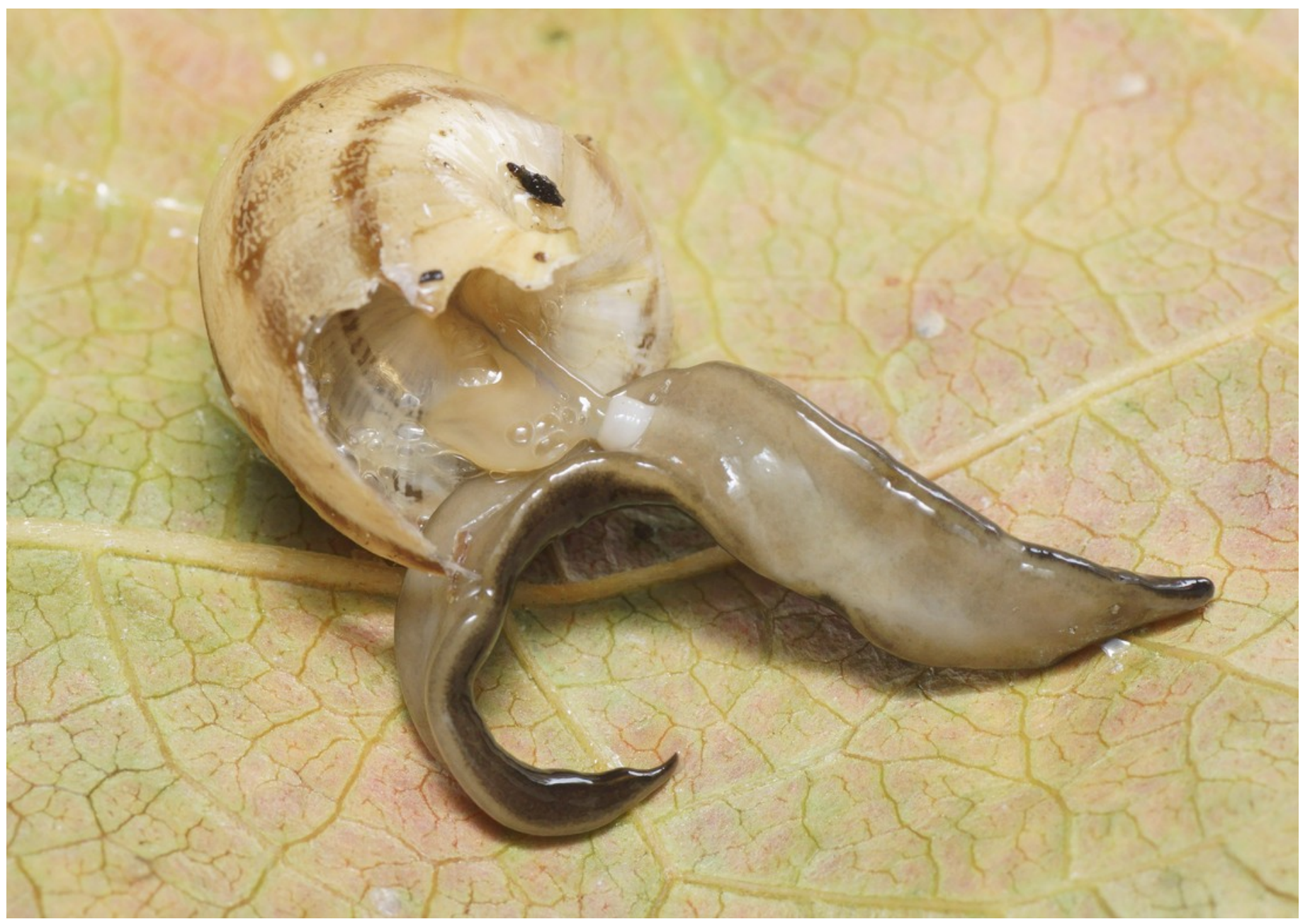

